\title{
Potential uptake of dissolved organic matter by seagrasses and macroalgae
}

\author{
Tom Van Engeland ${ }^{1, *}$, Tjeerd J. Bouma ${ }^{1}$, Edward P. Morris ${ }^{2}$, Fernando G. Brun ${ }^{2}$, \\ Gloria Peralta ${ }^{2}$, Miguel Lara ${ }^{2}$, Iris E. Hendriks ${ }^{3}$, Karline Soetaert ${ }^{1}$, \\ Jack J. Middelburg ${ }^{1,4}$
}

${ }^{1}$ Centre for Estuarine and Marine Ecology (CEME), Netherlands Institute of Ecology (NIOO), PO Box 140, 4400 AC Yerseke, The Netherlands

${ }^{2}$ Department of Biology (Area of Ecology), Faculty of Environmental and Marine Science, University of Cadiz, 11510 Puerto Real, Cadiz, Spain

${ }^{3}$ Mediterranean Institute for Advanced Studies (IMEDEA), c/ Miquel Marquès 21, 07190 Esporles, Spain

${ }^{4}$ Faculty of Geosciences, Utrecht University, PO Box 80.021, 3508 TA Utrecht, The Netherlands

\begin{abstract}
Dissolved organic nitrogen (DON) acts as a large reservoir of fixed nitrogen. Whereas DON utilization is common in the microbial community, little is known about utilization by macrophytes. We investigated the ability of the coexisting temperate marine macrophytes Zostera noltii, Cymodocea nodosa, and Caulerpa prolifera to take up nitrogen and carbon from small organic substrates of different molecular complexities (urea, glycine, L-leucine, and L-phenylalanine) and from dissolved organic matter (DOM) derived from algal and bacterial cultures (substrates with a complex composition). In addition to inorganic nitrogen, nitrogen from small organic substrates could be taken up in significant amounts by all macrophytes. Substrate uptake by the aboveground tissue differed from that of the belowground tissue. No relationships between carbon and nitrogen uptake of small organics were found. The preference for individual organic substrates was related to their structural complexity and $\mathrm{C}: \mathrm{N}$ ratio. Uptake of algae-derived organic nitrogen was of similar magnitude as inorganic nitrogen, and was preferred over bacteria-derived nitrogen. These results add to the growing evidence that direct or quick indirect DON utilization may be more widespread among aquatic macrophytes than traditionally thought.
\end{abstract}

KEY WORDS: Uptake $\cdot$ Dissolved organic nitrogen $\cdot$ Stable isotopes $\cdot$ Zostera noltii $\cdot$ Cymodocea nodosa $\cdot$ Caulerpa prolifera $\cdot$ Seagrasses $\cdot$ Macroalgae

\section{INTRODUCTION}

Seagrass ecosystems are highly productive and exhibit a strong nutrient retention capacity (Stapel et al. 2001). The affinities and uptake rates of seagrasses for dissolved inorganic nitrogen (DIN) are high (Stapel et al. 1996), keeping ambient DIN concentrations low and potentially limiting for growth (Bulthuis et al. 1992). Under such conditions, efficient nutrient recycling represents a vital ecosystem function. Regenerated nitrogen can be supplied to primary producers in 2 ways: (1) DIN uptake after remineralization of dissolved organic matter (DOM; Zehr \& Ward 2002), and (2) direct uptake of dissolved organic nitrogen $\left(\mathrm{DON}_{i}\right.$ Bronk et al. 2007). Therefore, DON may have an important role in nitrogen cycling within systems characterized by low inorganic nitrogen concentrations.

Despite its long-standing recognition as potential nutrient source, DON utilization by primary producers is not well understood (Bronk et al. 2007). Many phytoplankton taxa can use DON directly through processing mechanisms, such as urease activity and amino acid oxidation (Palenik \& Morel 1991, Mulholland et al. 2002, Stoecker \& Gustafson 2003, Solomon \& Glibert 
2008). But it is not yet known to what extent macrophytes share these capabilities. Although small organic compounds were until recently not considered a significant direct nutrient source for seagrasses (Romero et al. 2006), uptake of organic matter-derived nitrogen has been demonstrated for a number of macroalgae and seagrass species (Bird et al. 1998, Tyler et al. 2003). Uptake of detritus-derived compounds by seagrasses was demonstrated by Evrard et al. (2005) and Barrón et al. (2006). However, these studies did not differentiate between direct DON uptake and uptake after remineralization by the bacterial community. On the other hand, macrophyte DON uptake in axenic cultures has been observed (Bird et al. 1998, Tarutani et al. 2004), suggesting that direct utilization of DON may be more common than is generally realized.

Studying the uptake of natural DON (a complex mixture of organic nitrogen compounds) is inherently complicated. Not all compounds are treated the same way by primary producers. Tyler et al. (2005) demonstrated clear differences in the processing of 2 amino acids (alanine versus glycine) by a macroalga. Harrison et al. (2007) found relationships between amino acid complexity and uptake preference by terrestrial plants. Not all primary producers are equally capable of taking up organic nitrogen. Uptake capabilities for different compounds may even vary seasonally in certain microphytobenthic taxa (Nilsson \& Sundbäck 1996). This differentiation by primary producers between different types of organic molecules presents a complicating factor in studies on DON variability and uptake. This can be extrapolated to entire DON pools, where differences in DON composition and origin (e.g. algal versus bacterial, benthic versus pelagic, or spring floods versus baseflow conditions in rivers) may be manifest as differences in bioavailability and processing mechanisms (Ziegler \& Benner 1999, Stepanauskas et al. 2000, McCarthy et al. 2004). Moreover, uptake of nitrogen by macrophytes is often different between above- and belowground parts (Thursby \& Harlin 1984, Vonk et al. 2008). Therefore, understanding the variety of DON processing mechanisms present in primary producers may help to explain the large seasonal variability in DON concentrations and differences in reactivity observed between studies and ecosystems (Bronk 2002, Van Engeland et al. 2010).

Given the potential importance of DON as source of nitrogen in macrophyte-dominated systems, it is imperative that we gain more insight in the role of this highly complex and little understood ecosystem component. Hence, we conducted an uptake experiment in the laboratory with 3 co-occurring temperate macrophyte species from Cadiz Bay (Spain): the seagrasses Zostera noltii and Cymodocea nodosa, and Caulerpa prolifera, a rhizoid forming macroalga. The main objectives of this study are (1) to assess whether uptake of organic matter derived nitrogen and/or carbon by macrophytes occurs, (2) to compare uptake of different inorganic $\left(\mathrm{NH}_{4}{ }^{+}\right.$and $\mathrm{NO}_{3}{ }^{-}$) and organic (urea, glycine, leucine, phenylalanine, algae-derived DOM, and bacteria-derived DOM) nitrogen sources of contrasting complexity and C:N ratio, and (3) to compare nitrogen uptake by aboveground and belowground plant tissues. Isotope dual-labeled substrates $\left({ }^{13} \mathrm{C}\right.$ and ${ }^{15} \mathrm{~N}$ ) allowed for the separation of uptake via other fluxes out of the substrate pool, and to track carbon uptake and nitrogen uptake separately.

\section{MATERIALS AND METHODS}

Experimental set-up. Specimens of Zostera noltii Hornem, Cymodocea nodosa Ucria (Ascherson) and Caulerpa prolifera (Forsskål) J. V. Lamouroux were collected in the field near Santibañez (36 $28^{\circ} 12.79^{\prime \prime} \mathrm{N}$, $6^{\circ} 15^{\prime}$ 7.07" W; Cadiz, Spain) and immediately brought to the laboratory. Epiphytes were removed from the aboveground plant parts by gently scraping with a razor blade. Filtered water (GF/F filter, Whatman) from the same location was used as incubation medium, containing the following concentrations of sources of inorganic and organic nitrogen: $\mathrm{NH}_{4}{ }^{+}=0.3 \pm 0.06 \mu \mathrm{mol}$ $\mathrm{l}^{-1} ; \mathrm{NO}_{3}^{-}=0.7 \pm 0.38 \mu \mathrm{mol} \mathrm{l}{ }^{-1}$; urea $=2.2 \pm 0.24 \mu \mathrm{mol} \mathrm{l}{ }^{-1}$; $\mathrm{DON}=16.4 \pm 0.77 \mu \mathrm{mol} \mathrm{l^{-1 }}$; glycine $=23.7 \pm 3.6 \mathrm{nmol}$ $\mathrm{l}^{-1} ;$ leucine $=0.6 \pm 0.4 \mathrm{nmol} \mathrm{l^{-1 }}$; phenylalanine $=4.8 \pm$ $0.7 \mathrm{nmol} \mathrm{l}^{-1}$ (all values: mean $\pm \mathrm{SE}$ ). Note that $\mathrm{GF} / \mathrm{F}$ filters retain a part of the bacterial community but not all bacteria. The incubations were performed in a climatecontrolled room. Macrophytes were left intact with their aboveground and belowground parts in separate plastic cups $(123 \mathrm{ml})$. Cups were filled almost to the top so as to minimize local desiccation of the plants where they protruded out of the water, while care was taken to prevent mixing of water between cups via capillary effects or spilling. Inorganic and organic compounds (Cambridge Isotope Laboratories) of various molecular complexities, further referred to as substrates (substances that are acted upon by an enzyme), were added to the 'aboveground cup' in the aboveground treatments and to the 'belowground cup' in the belowground treatments (Fig. 1), so as to reach final concentrations indicated in Table 1. Plants were incubated for $\sim 3 \mathrm{~h}$ in a full factorial design with 3 species, 8 substrates, 2 incubations (aboveground vs. belowground), and 3 replicates. Extra plants were collected to measure the natural abundance (isotope fractions) of ${ }^{13} \mathrm{C}$ and ${ }^{15} \mathrm{~N}$ in the relevant plant parts. The water in the cups was constantly stirred to prevent local depletion of substrate. To avoid experimental artifacts, substrate 


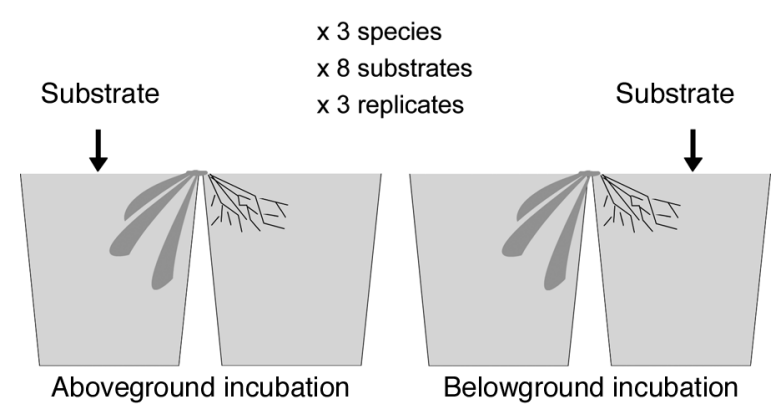

Fig. 1. Experimental setup. Substrate was added to the relevant cups in the aboveground and belowground treatments. This was performed in triplicate for the 3 macrophytes and 8 substrates

concentrations were kept close to those found in the water column of the bay (see above and Table 1). Although this means that the substrate could be depleted, this was not an issue since our primary objective was to determine if macrophytes could utilize DON of different complexities/composition rather than accurately quantifying uptake kinetics. After incubation, the plants were rinsed with clean filtered seawater, dabbed with tissues, dissected, frozen at $-20^{\circ} \mathrm{C}$, freeze dried, weighed and ground to a fine powder. $C$. nodosa leaves, sheaths, rhizome, and roots were processed separately. Because of the low plant biomass, Z. noltii was dissected into aboveground and belowground (i.e. rhizome + root) parts. C. prolifera individuals were dissected into 3 sections; assimilators, stolons, and rhizoids (analogs of leaves, stems and roots, respectively).

Inorganic and organic substrates. This study was based on stable isotope labeled substrates, which has the advantage over a mass balance approach that uptake can be distinguished from other effluxes out of the different source pools. The magnitude of $\mathrm{NH}_{4}{ }^{+}$and $\mathrm{NO}_{3}{ }^{-}$served as reference for comparison with organic nitrogen uptake. Urea and the amino acids glycine, Lleucine and L-phenylalanine (all ${ }^{13} \mathrm{C}$ and ${ }^{15} \mathrm{~N}$ double labeled) were used to examine the substrate preference of small individual organic nitrogen sources with contrasting complexity, $\mathrm{C}: \mathrm{N}$ ratio and molar mass (Table 1). Glycine is a fairly simple achiral amino acid with hydrogen as R-group. Leucine is more complex and chiral with an iso-butyl group on the $\alpha$-carbon, and often used as a tool to measure bacterial activity (Kirchman et al. 1985). Phenylalanine has a benzenelike ring (phenyl) as R-group, which is considered chemically stable (resistant to breakdown). We cautiously assumed that, at least to some extent, this chemical stability affects the overall biological reactivity. The abundance of these amino acids in organisms and bacteria may also hint at their overall bioavailability (Table 1), assuming a certain correspondence between abundance in particulate organic matter (POM) and exchange (uptake/release) with the DOM pool. Finally, 2 complex DOM pools were used to mimic naturally occurring complex DOM typical of marine environments (also double labeled; see follow-

Table 1. The substrates used for this experiment. Algae- and bacteria-DOM were synthetic dissolved organic matter (DOM) substrates used to mimic complex DOM typical of marine environments. The columns show labeling, isotopes, abbreviations used in tables and figures, their final concentrations in the incubations, the C:N ratio, the approximate molar mass of the small organic molecules, and the chemical structure of the small organic compounds. For the amino acids their range in relative abundance of total hydrolysable amino acids in organisms is also given, based on data from Cowie \& Hedges (1992)

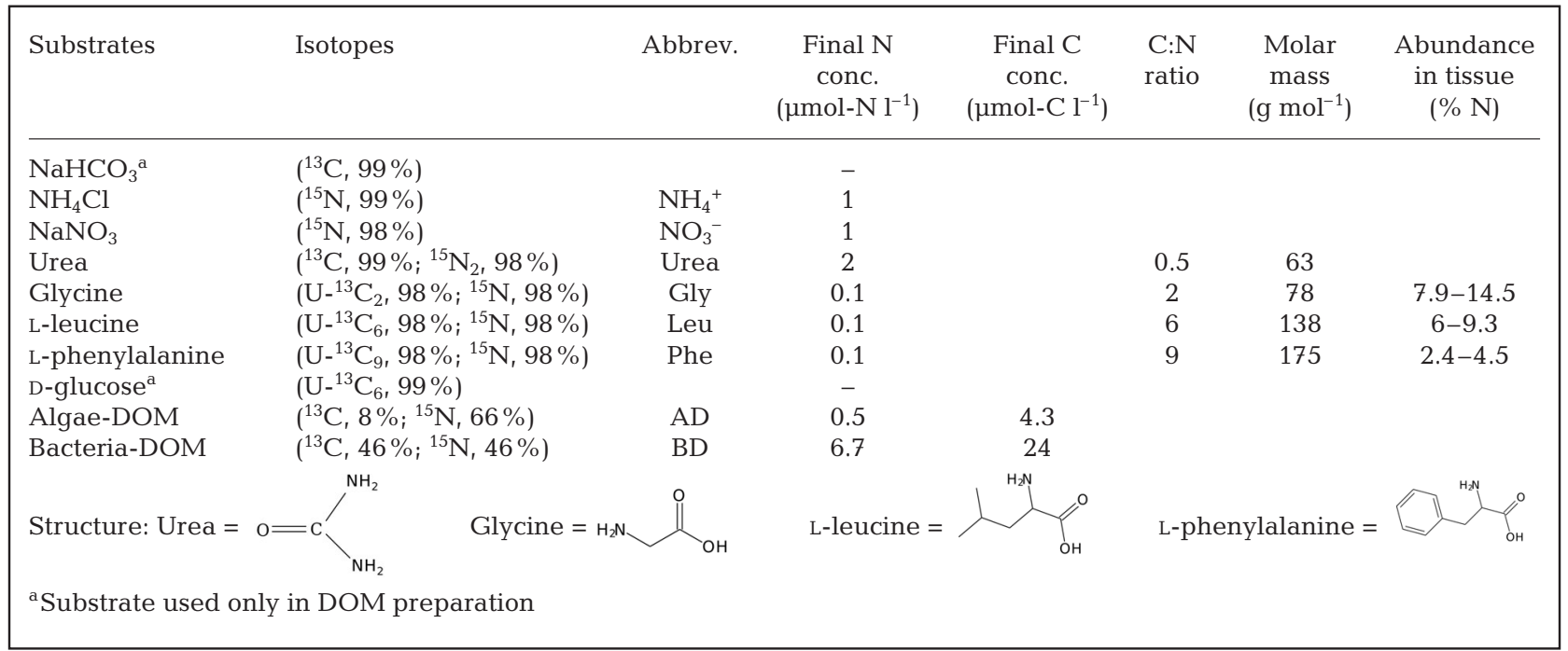


ing section). Both the nitrogen and carbon were present as heavy isotopes in the organic substrates (Table 1), enabling us to examine the potential coupling of carbon and nitrogen uptake.

Preparation of algae- and bacteria-derived DOM. Besides the individual organic compounds mentioned above, 2 DOM substrates with a complex composition were created; 1 from a culture of soil bacteria grown on ${ }^{13} \mathrm{C}$-glucose and ${ }^{15} \mathrm{NH}_{4} \mathrm{Cl}$, and 1 from an axenic culture of Skeletonema costatum grown on $\mathrm{NaH}^{13} \mathrm{CO}_{3}$ and $\mathrm{Na}^{15} \mathrm{NO}_{3}$. After incubation, the cells were freeze dried, added to $10 \mathrm{ml}$ of Milli-Q water and shaken for $48 \mathrm{~h}$ at room temperature after addition of Devarda's alloy and $\mathrm{MgO}$ to remove inorganic nitrogen. Particles were removed by centrifugation. The supernatants were diluted to $20 \mathrm{ml}$ and kept frozen at $-20^{\circ} \mathrm{C}$ until further use (i.e. addition to the incubation chambers).

The DON concentrations in the concentrated algae-derived and bacteria-derived substrates were $14.6 \mathrm{mmol}-\mathrm{N} \mathrm{l}^{-1}$ and $19.3 \mathrm{mmol}-\mathrm{N} \mathrm{l}^{-1}$ respectively. The dissolved organic carbon (DOC) concentrations were

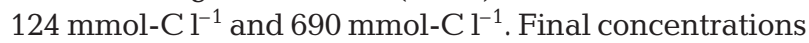
of added DON and DOC in the treatments are listed in Table 1. Dissolved combined amino acids (DCAA) comprised $84 \pm 24 \%$ (algae-derived) and $47 \pm 11 \%$ (bacteriaderived) of the DON, and $34 \pm 11 \%$ (algae-derived) and $46 \pm 12 \%$ (bacteria-derived) of the DOC. The dissolved free amino acid (DFAA) fraction was dominated by L-arginine and L-glutamine, and L-arginine and L-glutamate for the algae- and bacteria-derived DON, respectively (data not shown). L-alanine and L-leucine were dominant in the DCAA fraction of both bacteria- and algae-derived DON (data not shown), confirming the difference in chemical composition between the algae- and bacteria-derived DOM substrates.

Stable isotope and nutrient measurements. DIN concentrations $\left(\mathrm{NH}_{4}{ }^{+}+\mathrm{NO}_{2}{ }^{-}+\mathrm{NO}_{3}{ }^{-}\right)$and urea were determined colorimetrically in filtered incubation medium (GF/F filter, Whatman). DON was calculated as the difference between total dissolved nitrogen (TDN), determined as $\mathrm{NO}_{3}{ }^{-}$after an alkaline persulphate destruction (Hansen \& Koroleff 1999), and DIN. DOC concentrations were measured with a Skalar SK12 organic carbon analyzer after filtering the water over a GF/6 filter (Whatman). DFAA were determined prior to hydrolysis using a Waters HPLC system with a 996 photodiode array detector, total hydrolysable amino acids (THAA) post hydrolysis, and DCAA was calculated as THAA - DFAA.

Carbon and nitrogen content, and relative abundances of ${ }^{13} \mathrm{C}$ and ${ }^{15} \mathrm{~N}$ in the tissue, as well as concentrated DOM substrate, were measured using a Thermo EA 1112 elemental analyzer coupled to a Thermo Delta $\mathrm{V}$ Advantage isotope ratio mass spectrometer with a ConFlo II interface (EA-IRMS).
Data treatment. Due to the wide range of labeling intensities our calculations were based on isotope fractions $(F)$ instead of $\delta$-values (Fry 2006). Isotope excesses $\left(E_{\text {sample }}\right)$ were calculated as the difference between the isotope fraction in the sample ( $\left.F_{\text {sample }}\right)$ and the natural abundance (i.e. initial isotope fractions; $F_{\text {nat }}$ ):

$$
E_{\text {sample }}=F_{\text {sample }}-\mathrm{F}_{\text {nat }}
$$

Specific uptake rates of heavy isotope, $V_{\text {sample }}\left(\mu \mathrm{mol}\left[{ }^{13} \mathrm{C}\right.\right.$ or $\left.{ }^{15} \mathrm{~N}\right] \mathrm{mg} \mathrm{DW}^{-1} \mathrm{~h}^{-1}$ ), were calculated as the quotient:

$$
V_{\text {sample }}=\mathrm{POM} \times E_{\text {sample }} /(\text { time } \times \text { dry weight })
$$

where POM is the biomass of the plant tissue $\left(\mu \mathrm{mol}{ }^{13} \mathrm{C}\right.$ or ${ }^{15} \mathrm{~N}$ ). These specific uptake rates allowed comparisons between different species and individuals with varying biomass. Corrections for varying substrate concentrations were accomplished by dividing $V_{\text {sample }}$ by the substrate concentration, in terms of nitrogen or carbon added, and multiplying by 100 to convert to $\%$ (mg DW) $)^{-1} \mathrm{~h}^{-1}$ (Fig. 2):

$$
\% V_{\text {sample }}=100 \times V_{\text {sample }} / \mathrm{C}_{\text {added }}\left(\text { or } \mathrm{N}_{\text {added }}\right)
$$

This specific uptake rate normalized to the amount of substrate initially available gives a rough indication of the plant's preference for a particular nutrient source, and can be interpreted as an uptake rate per amount of substrate available. Note that $\% V_{\text {sample }}$ in treatments with equal amounts of added substrate can be compared as if they were specific uptake rates. The total amount of heavy isotope taken up $\left({ }^{15} \mathrm{~N}\right.$ incorporation; $\left.I_{\text {sample }}\right)$ during the incubation $(\sim 3 \mathrm{~h})$ was calculated as:

$$
I_{\text {sample }}=E_{\text {sample }} \times \mathrm{POM}
$$

expressed in $\mu \mathrm{mol}$. Differences between total incorporation and the initial concentration of substrate per treatment were examined statistically so as to assess potential depletion, and therefore underestimation of specific uptake rates. Treatments with significant substrate depletion cannot be used for comparisons of uptake rates.

Statistical analyses. The occurrence of ${ }^{15} \mathrm{~N}$ (or ${ }^{13} \mathrm{C}$ ) uptake (research question 1) and translocation was tested with $t$-tests by comparing initial isotope fractions (natural abundance) to the isotope fractions after incubation. Corrections for differences in variance per treatment were successfully performed by means of a variance function $\left(\sim \mathrm{SD}_{\mathrm{w}}{ }^{-2}\right.$, where $\mathrm{SD}_{\mathrm{w}}$ is the withingroup standard deviation). After this correction, no overall deviations from normality were detected in the residuals (Kolmogorov-Smirnov tests). Since we found indications of translocation, ${ }^{15} \mathrm{~N}$ incorporation from all plant parts were added together to account for the total amount of label taken up.

Differences between total ${ }^{15} \mathrm{~N}$ incorporation $\left(I_{\text {sample }}\right)$ and the initial concentration of substrate per treatment were examined by means of 1 -sample tests. 
Significant differences in the normalized uptake $\left(\% V_{\text {sample }}\right)$ of the different substrates by macrophyte species and their respective plant modules (aboveground vs. belowground), were investigated by means of variance analysis (research questions 2 and 3). Normalized uptake was chosen as the response variable because it includes corrections for both biomass and initial substrate concentrations. Corrections for heteroscedasticity were performed by logarithmic transformation of the response variable ( $\left.\% V_{\text {sample }}\right)$. All tests were done at the $5 \%$ significance level. Differences between group means within the ANOVA setting
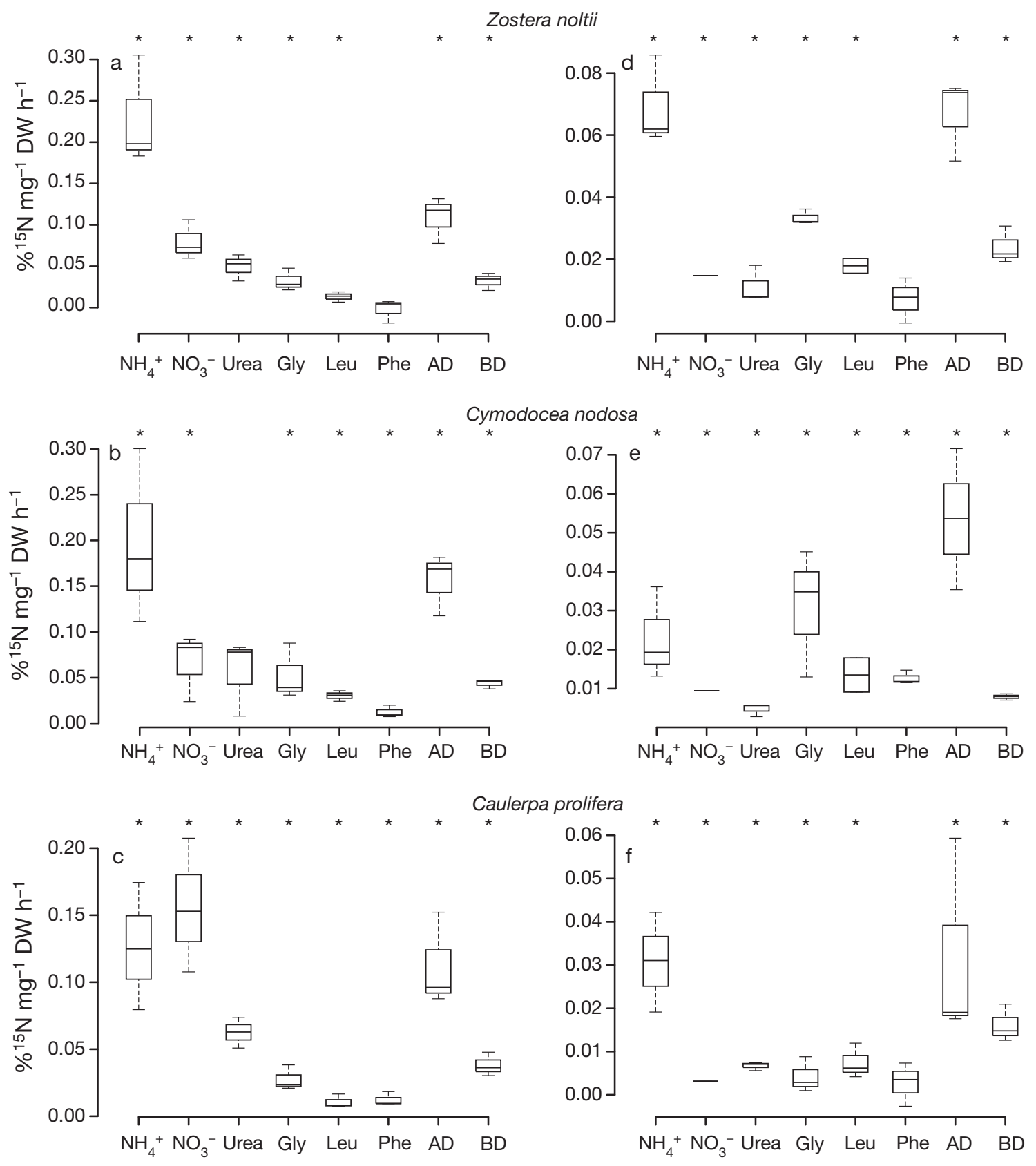

Fig. 2. Normalized uptake ( $\% V_{\text {sample}}$ ) of ${ }^{15} \mathrm{~N}$ from different substrates (see Table $1 \mathrm{for}$ abbreviations) by the aboveground (left) and belowground tissue (right) of (a, d) Zostera noltii, (b, e) Cymodocea nodosa, and (c, f) Caulerpa prolifera, expressed as a percentage of the added substrate per milligram of tissue dry weight and per hour of incubation time (boxplots show median, interquartile range $=$ box, extremes $=$ whiskers). Translocation was taken into account. Significant excesses (95\% confidence level) in heavy isotope fractions per treatment relative to the natural heavy isotope fractions in the macrophyte tissue are indicated with an asterisk (along the top of the graph). Note the differences in scales between the different graphs 
(species $\times$ plant module $\times$ substrate combinations) were tested by Tukey's HSD (honest significant difference) test.

Examination of significant relationships between $\% V_{\text {sample }}$ and C:N ratios of the substrates (here used as a proxy for chemical complexity and molecule size) was carried out by means of model 1 linear regression on the average values per species and treatment.

\section{RESULTS}

\section{Nitrogen enrichment and incorporation}

${ }^{15} \mathrm{~N}$ excesses $\left(E_{\text {sample }}\right)$ in the aboveground plant modules of the aboveground treatments were significantly different than zero for all 3 macrophyte species; except

Table 2. Results from the $t$-tests per macrophyte species and per incubation (aboveground or belowground) for the difference in ${ }^{15} \mathrm{~N}$ atomic fractions (with consideration of translocation) after incubation relative to the natural abundance in the plant parts that directly received labeled substrate. Significant ${ }^{15} \mathrm{~N}$ enrichments, reflecting ${ }^{15} \mathrm{~N}$ uptake, are also indicated with asterisks above the boxplots in Fig. 2 (see Table 1 for abbreviations)

\begin{tabular}{|c|c|c|c|c|}
\hline \multirow[t]{2}{*}{ Treatment } & \multicolumn{2}{|c|}{ Aboveground } & \multicolumn{2}{|c|}{ Belowground } \\
\hline & $t$ & $\mathrm{p}$ & $t$ & $\mathrm{p}$ \\
\hline \multicolumn{5}{|c|}{ Zostera noltii } \\
\hline $\mathrm{NH}_{4}^{+}$ & 9.2 & $<0.001$ & 7.2 & $<0.001$ \\
\hline $\mathrm{NO}_{3}^{-}$ & 9.8 & $<0.001$ & 15.4 & $<0.001$ \\
\hline UR & 2.9 & 0.009 & 5.1 & $<0.001$ \\
\hline Gly & 2.7 & 0.015 & 7.1 & $<0.001$ \\
\hline Leu & 3.3 & 0.004 & 5.9 & $<0.001$ \\
\hline Phe & 0.0 & 0.975 & 1.5 & 0.143 \\
\hline $\mathrm{AD}$ & 4.3 & $<0.001$ & 6.9 & $<0.001$ \\
\hline $\mathrm{BD}$ & 2.8 & 0.012 & 6.5 & $<0.001$ \\
\hline \multicolumn{5}{|c|}{ Cymodocea nodosa } \\
\hline $\mathrm{NH}_{4}^{+}$ & 13 & $<0.001$ & 14.3 & $<0.001$ \\
\hline $\mathrm{NO}_{3}^{-}$ & 2.2 & 0.042 & 553 & $<0.001$ \\
\hline UR & 1.9 & 0.076 & 6.6 & $<0.001$ \\
\hline Gly & 3 & 0.007 & 3.4 & 0.004 \\
\hline Leu & 3.4 & 0.003 & 12.1 & $<0.001$ \\
\hline Phe & 4 & 0.001 & 11 & $<0.001$ \\
\hline $\mathrm{AD}$ & 4.9 & $<0.001$ & 8.9 & $<0.001$ \\
\hline $\mathrm{BD}$ & 5.5 & $<0.001$ & 52.8 & $<0.001$ \\
\hline \multicolumn{5}{|c|}{ Caulerpa prolifera } \\
\hline $\mathrm{NH}_{4}^{+}$ & 10.7 & $<0.001$ & 4.7 & $<0.001$ \\
\hline $\mathrm{NO}_{3}^{-}$ & 4.1 & 0.001 & 4.3 & $<0.001$ \\
\hline UR & 5.4 & $<0.001$ & 8.3 & $<0.001$ \\
\hline Gly & 4.4 & $<0.001$ & 2.7 & 0.015 \\
\hline Leu & 4.3 & $<0.001$ & 5.3 & $<0.001$ \\
\hline Phe & 4.9 & $<0.001$ & 2 & 0.058 \\
\hline $\mathrm{AD}$ & 22 & $<0.001$ & 3.8 & 0.001 \\
\hline BD & 35 & $<0.001$ & 3.5 & 0.002 \\
\hline
\end{tabular}

for the phenylalanine addition to Zostera noltii and the urea addition to Cymodocea nodosa (Fig. 2a-c, Table 2 left columns). For the belowground treatments, significant ${ }^{15} \mathrm{~N}$ excesses were found in the belowground tissues of all species; except for the phenylalanine addition to Z. noltii and to Caulerpa prolifera (Fig. 2d-f, Table 2 right column). Hence, significant uptake of ${ }^{15} \mathrm{~N}$ by both above- and belowground parts of all species was found in the majority of substrate treatments.

The occurrence of translocation between modules during the incubation period was tested by examining for significant ${ }^{15} \mathrm{~N}$ excesses in the plant parts that were not directly in contact with the labeled medium (i.e. belowground tissues in the aboveground treatment and vice versa). For Caulerpa prolifera, downward translocation was only encountered in the $\mathrm{NH}_{4}{ }^{+}$and algae-derived DON additions ( $t$-tests, $\mathrm{p}<0.05)$. Inorganic nitrogen, algae-derived, and bacteria-derived DON were also transported downward in the seagrasses ( $t$-tests, $\mathrm{p}<0.05$ ). Upward translocation was found in all Cymodocea nodosa substrate treatments ( $t$-tests, p < 0.05), except phenylalanine. For Zostera noltii upward translocation was significant in all treatments ( $t$-tests, $\mathrm{p}<0.05$ ), except for the individual organic compounds (urea, glycine, leucine, and phenylalanine). Because significant translocation was found in many of the treatments, ${ }^{15} \mathrm{~N}$ and ${ }^{13} \mathrm{C}$ uptake in the remainder of the results section is considered for the entire plant.

Potential substrate depletion during the $3 \mathrm{~h}$ incubation period was assessed by comparing total ${ }^{15} \mathrm{~N}$ incorporation $(I)$ to the initial amount of ${ }^{15} \mathrm{~N}$ added to each treatment. In the aboveground incubations of Caulerpa prolifera, the amount of ${ }^{15} \mathrm{~N}$ incorporated within tissues was not significantly different from the amount of ${ }^{15} \mathrm{~N}$ added as $\mathrm{NH}_{4}{ }^{+}, \mathrm{NO}_{3}{ }^{-}$and algae-derived DON (1-sample $t$-tests, $\mathrm{p}>0.05)$. Thus, substrate depletion may have occurred in these treatments, and comparison of uptake rates should be made with caution. The same was true for the algae-derived DON addition to Cymodocea nodosa aboveground parts (1-sample $t$-test, $\mathrm{p}>0.05)$. Total ${ }^{15} \mathrm{~N}$ incorporation in the rest of the treatments (both above- and belowground) remained well below the initial amounts of substrates added (1-sample $t$-tests, always $\mathrm{p}<0.05)$.

\section{Nitrogen uptake preferences}

A 3-way analysis of variance (macrophyte species $\times$ plant module $\times$ substrate) illustrated significant effects of factors and first-order interactions (Table 3), indicating ${ }^{15} \mathrm{~N}$ substrate preferences were dependent upon both macrophyte species and the respective plant module examined. 
Table 3. Analysis of variance table from the 3-factor model with substrate preference as response variable and species, plant module (aboveground vs. belowground) and substrate main effects and all possible interactions

\begin{tabular}{|lrrr|}
\hline $\mathrm{df}_{\text {denominator }}$ : 102 & $\mathrm{df}_{\text {numerator }}$ & $F$ & $\mathrm{p}$ \\
\hline Species & 2 & 3.4 & 0.036 \\
Incubation & 1 & 176 & $<0.001$ \\
Substrate & 7 & 56 & $<0.001$ \\
Species $\times$ Incubation & 2 & 8.4 & $<0.001$ \\
Species $\times$ Substrate & 14 & 3.3 & $<0.001$ \\
Incubation $\times$ Substrate & 7 & 17 & $<0.001$ \\
Species $\times$ Incubation $\times$ Substrate & 14 & 1.0 & 0.49 \\
\hline
\end{tabular}

In the aboveground treatments normalized uptake rates ( $\% V_{\text {sample }}$ ) of $\mathrm{NH}_{4}{ }^{+}$were significantly higher than for all other substrates (Fig. 2a-c; Tukey HSD, always $\mathrm{p}<0.05)$, except for the algae-derived DON additions to Cymodocea nodosa and Caulerpa prolifera, and the $\mathrm{NO}_{3}{ }^{-}$addition to $C$. prolifera (although note that substrate depletion was found in these treatments). Normalized uptake rates of algae-derived DON were similar to $\mathrm{NO}_{3}{ }^{-}$in Zostera noltii and C. prolifera, and similar to $\mathrm{NH}_{4}{ }^{+}$in C. nodosa (Tukey HSD, p > 0.05). In the belowground treatments $Z$. noltii exhibited a significantly higher preference for $\mathrm{NH}_{4}{ }^{+}$than for urea, leucine, phenylalanine, and bacteria-derived DON (Tukey HSD, $\mathrm{p}<0.05$ ). Algae-derived DON \% $V_{\text {sample }}$ of algae-derived DOM was significantly higher than for urea and phenylalanine in both seagrasses.

Algae-derived DON was always preferred over bacteria-derived DON in the aboveground incubations (Tukey HSD, always $\mathrm{p}<0.01$; Fig. 2a-c). In the belowground treatments a significant difference between algae- and bacteria-derived DON normalized uptake was detected for Cymodocea nodosa. (Tukey HSD, p < 0.05). A tendency for higher algae-derived DON uptake existed for Zostera noltii $(\mathrm{p}=0.07)$, indicating that a distinction was made between algae- and bacteriaderived DON as a nitrogen source.

The normalized uptake rates of individual organic compounds (urea, glycine, leucine, and phenylalanine) by aboveground tissues were significantly lower than for algae-derived DON and $\mathrm{NH}_{4}{ }^{+}$(Fig. 2a-C; Tukey HSD, always $\mathrm{p}<0.05$ ); except for the urea addition to Caulerpa prolifera. Differences in the normalized uptake between these individual compounds were not always significant, however uptake rates of urea were higher than phenylalanine for C. prolifera and Zostera noltii (Tukey HSD, p < 0.01), and Cymodocea nodosa had a strong tendency towards urea preference (Tukey HSD, $p=0.055)$. A significant negative linear relationship was found between the $\mathrm{C}: \mathrm{N}$ ratio of the individual organic compounds and the normalized uptake rates of

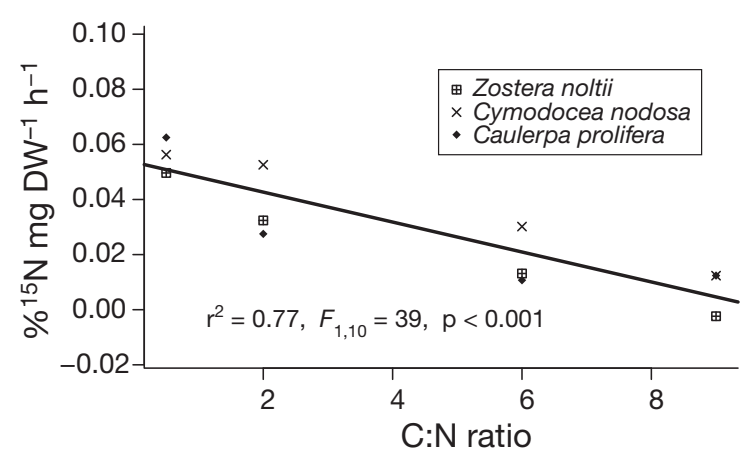

Fig. 3. Linear regression of the ${ }^{15} \mathrm{~N}$ substrate preference versus the $\mathrm{C}: \mathrm{N}$ ratio of the organic substrates urea $(\mathrm{C}: \mathrm{N}$ ratio $=$ $0.5)$, glycine (2), leucine (6), and phenylalanine (9), and the coefficient of determination of the regression model

aboveground tissues (Fig. 3), whereas no relationship was found for the belowground modules.

\section{Carbon enrichments}

For the treatments where double-labeled $\left({ }^{15} \mathrm{~N}\right.$ and ${ }^{13} \mathrm{C}$ ) substrates were used (algae- and bacteria-derived DOM), it was also possible to assess the potential coupling between ${ }^{13} \mathrm{C}$ and ${ }^{15} \mathrm{~N}$ uptake. Generally, the carbon signals were weaker than the corresponding nitrogen signals, and more variable per treatment (Fig. 4). Bacteria-derived DOM treatments received the highest ${ }^{13} \mathrm{C}$ additions and had significant ${ }^{13} \mathrm{C}$ excesses in all cases ( $t$-tests, $\mathrm{p}<0.001)$. Additions of urea and phenylalanine to aboveground Caulerpa prolifera tissues also resulted in significant ${ }^{13} \mathrm{C}$ enrichment $(t$-tests, $\mathrm{p}<$ 0.05). No consistent patterns could be identified between carbon and nitrogen isotope excesses, normalized uptake rates, or total incorporation (data not shown).

\section{DISCUSSION}

\section{DON as a nutrient source}

This experiment has illustrated the ability of 3 temperate marine macrophytes to take up nitrogen from both inorganic and organic sources within hours. Aboveground as well as belowground tissues took up organic nitrogen. The specific uptake rates normalized by initial substrate concentrations for DON derived from an axenic diatom culture were comparable to those for $\mathrm{NH}_{4}{ }^{+}$, which is assumed to be the preferred nitrogen source of seagrasses (Romero et al. 2006). This highlights the potential importance of DON as an 
immediate source of bioavailable nitrogen. The potential for utilization of detritus-derived nitrogen by seagrasses in oligotrophic systems was previously demonstrated by Evrard et al. (2005) and Barrón et al. (2006). However, in these studies, which were focused on sediment associated processes, incubations lasted between 1 to $7 \mathrm{~d}$ and, thus both direct uptake of DON and uptake of DIN following remineralization were included. By restricting incubations to $3 \mathrm{~h}$, remineralization is expected to be much lower in our experiment. Recently, short-term ( hours) organic nitrogen uptake via both aboveground and belowground tissues was also demonstrated for seagrass species in a tropical oligotrophic system (Vonk et al. 2008). However, to our
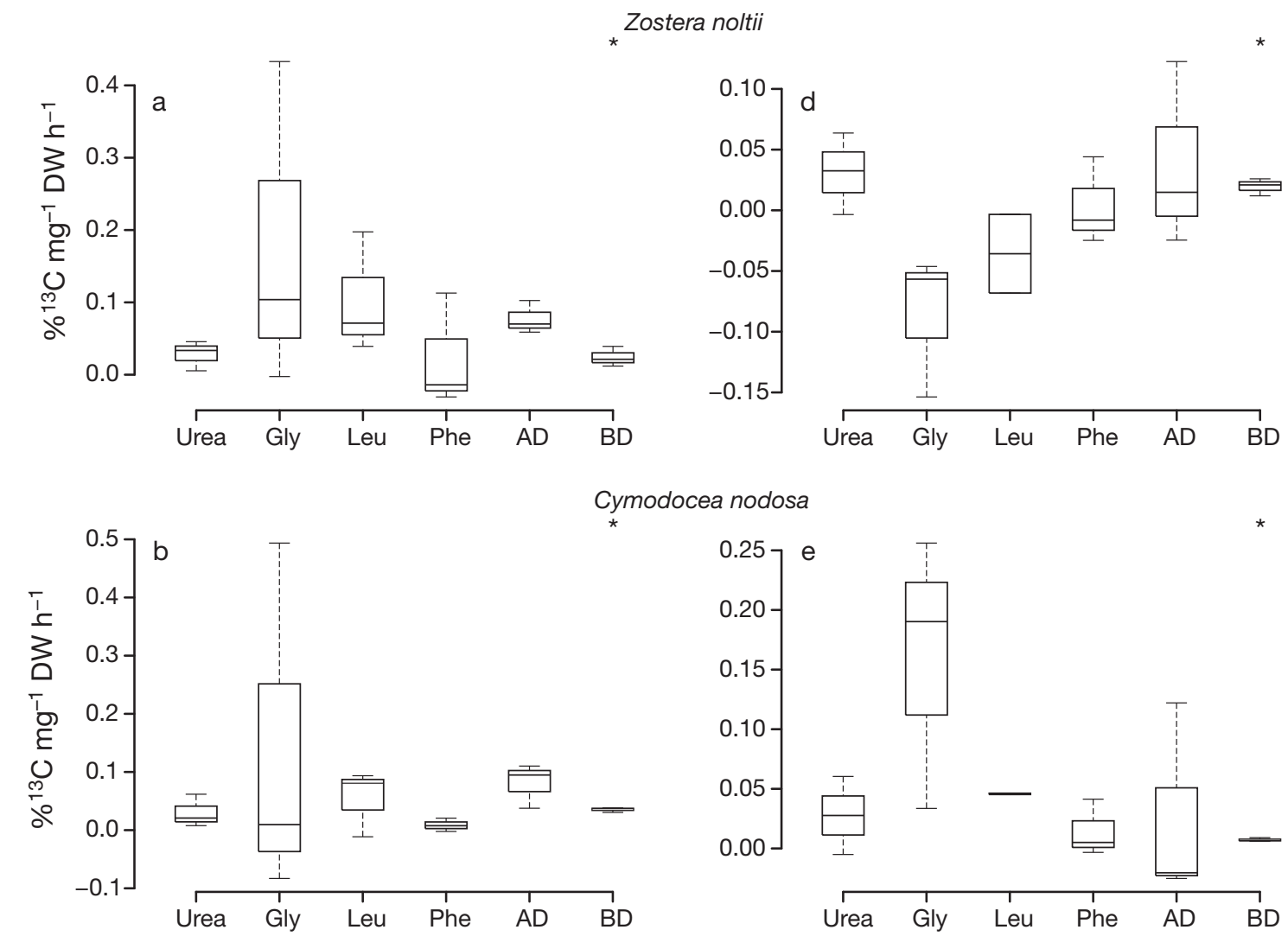

\section{ymodocea nodosa}
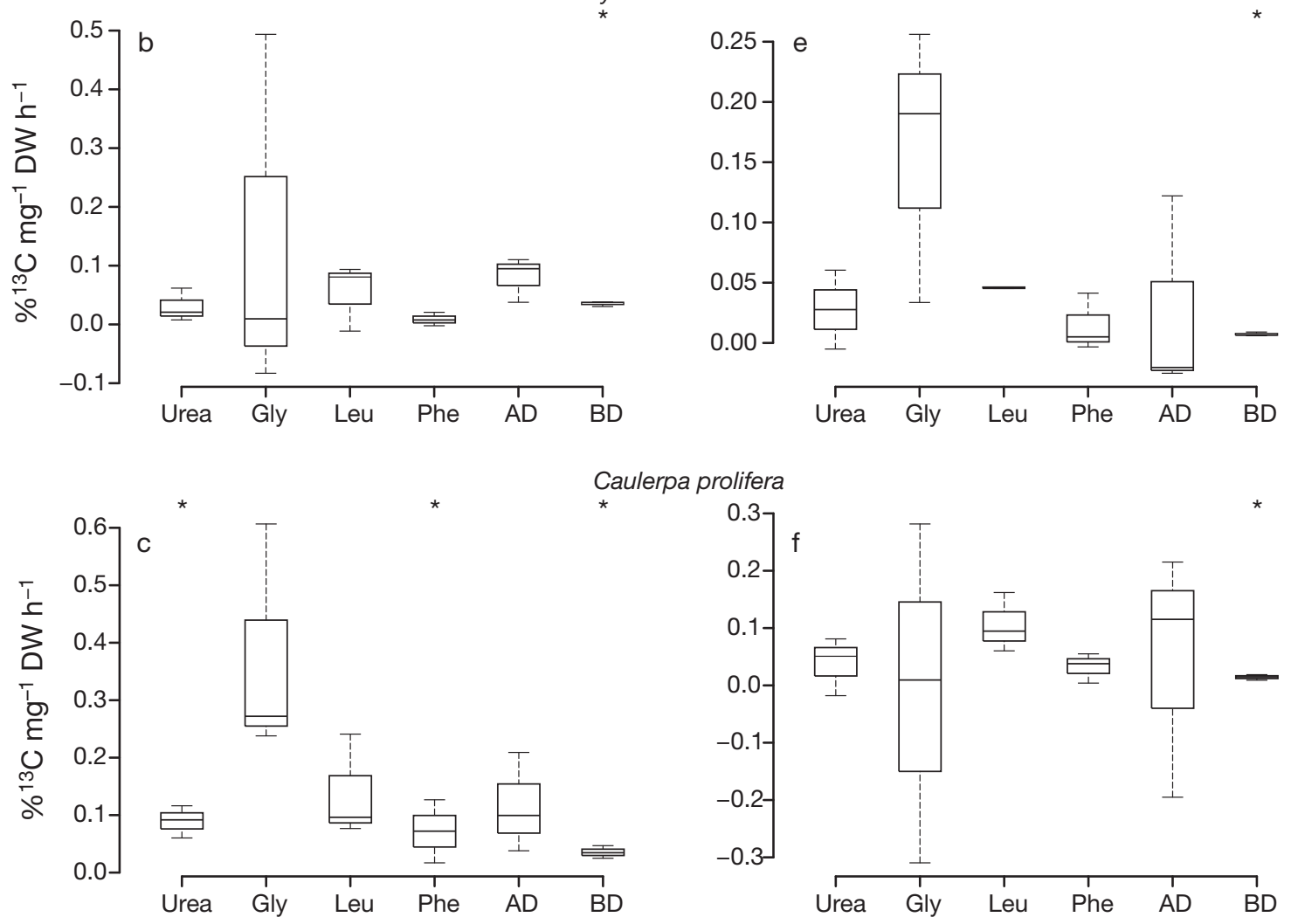

Caulerpa prolifera

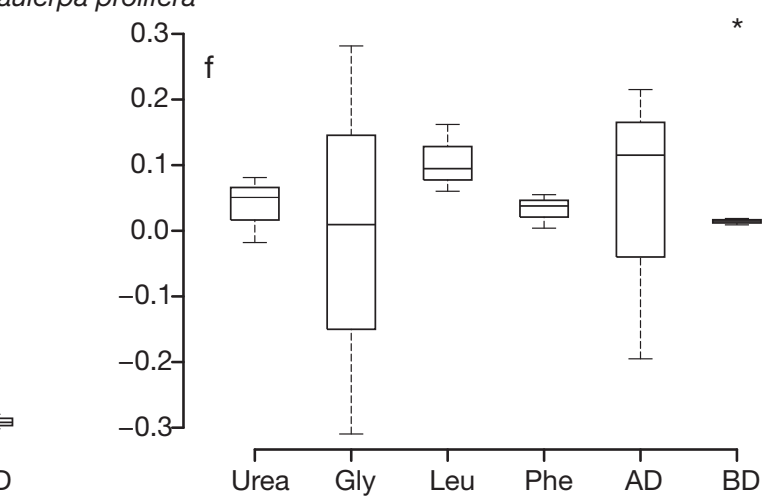

Fig. 4. Normalized uptake ( $\% V_{\text {sample}}$ ) of ${ }^{13} \mathrm{C}$ from different substrates (see Table 1 for abbreviations) by the aboveground (left) and belowground tissue (right) of (a, d) Zostera noltii, (b, e) Cymodocea nodosa, and (c, f) Caulerpa prolifera expressed as a percentage of the substrate added per milligram of tissue dry weight and per hour of incubation time ((boxplots show median, interquartile range $=$ box , extremes $=$ whiskers). Translocation was taken into account. in heavy isotope fractions per treatment relative to the natural heavy isotope abundance in the macrophyte tissue are indicated with an asterisk (along the top of the graphs). Note the differences in scales between the different graphs 
knowledge, our study is the first to systematically address short-term organic nitrogen utilization from specific compounds in temperate seagrasses.

Our study shows that, although nitrogen uptake occurred from both inorganic and organic substrates, not all substrates were treated similarly by the macrophytes. Inorganic nitrogen was preferred over individual organic compounds, mainly due to the high preference for ammonium (normalized uptake rates of nitrate were sometimes even lower than those of urea or glycine). Similar patterns were found for tropical seagrasses (Vonk et al. 2008). Ammonium is readily available for incorporation into amino acids, which gives an advantage over other substrates that have to be reduced or split. Indeed, studies on the interactions between ammonium and nitrate uptake in Zostera noltii suggest preferential use of ammonium when both substrates are present (Alexandre et al. 2010). Assimilatory nitrate reduction may in many cases still be cheaper than extracellular ammonification, because in the former case enzymes are re-used, and the resulting ammonium (after reduction) is not lost to the same extent as when produced externally.

Each type of small organic substrate was treated differently by the macrophytes. Based on this small set of compounds, there appeared to be a relationship between substrate $\mathrm{C}: \mathrm{N}$ ratios and uptake by aboveground tissues. Given the absence of significant carbon uptake in many treatments, one would not expect that substrate $\mathrm{C}: \mathrm{N}$ ratios could play such a direct role. However, a number of other factors are also related to the $\mathrm{C}: \mathrm{N}$ ratio of the substrates and might provide explanations for this consistent variation in preference; such as chemical structure (Table 1), the relative abundance within organisms and seagrass-dominated systems (Cowie \& Hedges 1992, Hansen et al. 2000), and their molar mass. Chemical structure may be important because of its effect on a substrates resistance to enzymatic breakdown (e.g. the increased chemical stability of an aromatic ring), but also because of enzyme substrate-specificity. Based on the decreasing relative abundance of amino acids from glycine to phenylalanine (Table 1; Cowie \& Hedges 1992, Hansen et al. 2000), one might hypothesize that enzyme expression may have been fine tuned to make optimal use of what is present in the environment. DON concentration and/or composition are indeed known to influence the activity of specific enzymes (Stepanauskas et al. 1999).

Although we found statistically significant differences between the spectrum of nitrogen sources preferred by the belowground tissues, post-hoc, multiple comparisons of differences between group-means generally failed due to limited statistical power. Nevertheless, our results give some indications that preferences for ammonium, glycine and algae-derived DON were roughly similar and tended to be higher than for the other substrates in the seagrasses. Caulerpa prolifera seemed to prefer ammonium and DON (algaederived and bacteria-derived) over other substrates. Although more replication will be needed to validate these patterns, they are in line with the results from Vonk et al. (2008). They also found higher uptake rates by seagrasses for an ammonium and amino acid mixture than for urea and nitrate. They suggested that root-mediated amino acid uptake might give seagrasses a competitive advantage over some macroalgae. Our results indeed seem to indicate that seagrasses roots tend to take up amino acids more easily than C. prolifera rhizoids. Overall, the present study supports the idea that, beside microphytobenthos, marine macrophytes are able to directly influence organic nitrogen fluxes from the sediment to the water column via uptake (Nilsson \& Sundbäck 1996, Tyler et al. 2003, Linares \& Sundbäck 2006)

Algae-derived DON was generally preferred over bacteria-derived DON, irrespective of the macrophyte species. The lower fraction of amino acids in bacteriaderived DON relative to algae-derived DON (see 'Materials and methods: Preparation of algae- and bacteria-derived DOM') may explain this preference, since it implies that other compounds, which may be more resistant to breakdown, are more abundant. These findings are in line with the observation that bacterial DON comprises a substantial fraction of the refractory part of oceanic DOM (McCarthy et al. 1998, 2004), although their study was mainly concerned with autotrophic cyanobacteria and much larger time scales. Our findings are thus in good agreement with the dependence of DON reactivity on DON composition and origin, found for other ecosystems (Ziegler \& Benner 1999, Seitzinger et al. 2002, McCallister et al. 2006), and in phytoplankton cultures (Pete et al. 2010). Thus, DON may play a role in community composition (e.g. seasonal succession patterns), just as other nutrients and their relative abundances do (e.g. $\mathrm{NH}_{4}{ }^{+}: \mathrm{NO}_{3}{ }^{-}$, N:P ratios, DIN/DON; Berg et al. 2003).

\section{Do macrophytes take up DON directly or only after remineralization to DIN?}

This study has revealed an uptake of nitrogen, but not carbon, originating from various organic substrates in a matter of hours. These results contrast those found for other macrophytes by Harrison et al. (2007) and Mozdzer et al. (2010), who found relationships between carbon and nitrogen uptake of amino acids related to their $\mathrm{C}: \mathrm{N}$ ratios. Previous research on organic carbon uptake in phytoplankton showed that this process and its coupling with organic nitrogen uptake 
strongly vary with species and substrates, and throughout the season (Mulholland et al. 2004, Andersson et al. 2006). In principle the absence of clear ${ }^{13} \mathrm{C}$ enrichment means that in our experiment either the nitrogen alone entered the plants, or the carbon was lost via breakdown of the substrates within the plant and subsequent carbon exudation. The uptake of nitrogen only requires degradation of the DOM by exoenzymes or cell-surface associated enzymes, and a subsequent transport of the smaller degradation products. The remaining carbon in the medium would be lost in a large background pool of DIC, or as carbon-rich organic matter. However, the fact that no relationship between carbon and nitrogen uptake was detected in our study, may also be due to the high carbon background in the macrophytes, which basically results in a low signal-to-noise ratio (von Felten et al. 2008).

The differences in the substrate preference between species and between plant parts implies that consistent distinctions were made by either the plants themselves or by associated bacteria. Seagrasses may indeed have specific bacterial communities attached to their root surfaces (Jensen et al. 2007). Although Caulerpa prolifera effectively repels epiphytes by the production of caulerpenine (Paul \& Fenical 1987), endosymbiotic prokaryotes have been shown to provide nitrogen to Caulerpa taxifolia (Chisholm et al. 1996). However, this was via fixation of dinitrogen that was transported by diffusion. Provided that endosymbionts can only process organic compounds within the tissue/cells, these compounds obviously have to be taken up or produced by the plant itself. We duly note however that macrophyte-bacteria interactions are highly speciesspecific and not well understood (Goecke et al. 2010), and thus it is not clear to what extent bacteria influenced our results. Nevertheless, even with the removal of epiphytes, phytoplankton and a part of the bacterial community, macrophytes are able to take up nitrogen from an organic origin practically immediately. A complex pool of DON can, therefore, supply nitrogen in quantities similar to or larger than inorganic pools, at close-to-ambient concentrations in temperate seagrass-dominated systems. Accordingly, DON should be included in future studies on nitrogen dynamics within seagrass systems.

Acknowledgements. This research was supported by the regional government of Andalusia project FUNDIV (P07RNM-2516), the Spanish Project CTM2008-00012/MAR, a European Reintegration Grant (MERG-CT-2007-205675), a travel grant from Schure-Beijerinck-Popping Fund (SBP/ JK/2007-32) and the Netherlands Organization for Scientific Research. Thanks to Fidel Echevarrìa Navas (Director of CACYTMAR) for granting us access to facilities, and to Bas Koutstaal for helping with sample processing. We also thank the anonymous reviewers for their valuable comments which significantly improved this manuscript.

\section{LITERATURE CITED}

Alexandre A, Silva J, Santos R (2010) Inorganic nitrogen uptake and related enzymatic activity in the seagrass Zostera noltii. PSZN I: Mar Ecol 31:539-545

Andersson MGI, Van Rijswijk P, Middelburg JJ (2006) Uptake of dissolved inorganic nitrogen, urea and amino acids in the Scheldt estuary: comparison of organic carbon and nitrogen uptake. Aquat Microb Ecol 44:303-315

Barrón C, Middelburg JJ, Duarte CM (2006) Phytoplankton trapped within seagrass (Posidonia oceanica) sediments are a nitrogen source: an in situ isotope labeling experiment. Limnol Oceanogr 51:1648-1653

> Berg GM, Balode M, Purina I, Bekere S, Bechemin C, Maestrini S (2003) Plankton community composition in relation to availability and uptake of oxidized and reduced nitrogen. Aquat Microb Ecol 30:263-274

Bird KT, Johnson JR, Jewett-Smith J (1998) In vitro culture of the seagrass Halophila decipiens. Aquat Bot 60:377-387

Bronk DA (2002) Dynamics of DON. In: Hansell DA, Carlson CA (eds) Biogeochemistry of marine dissolved organic matter. Academic Press, San Diego, CA, p 153-247

> Bronk DA, See JH, Bradley P, Killberg L (2007) DON as a source of bioavailable nitrogen for phytoplankton. Biogeosciences 4:283-296

Bulthuis DA, Axelrad DM, Mickelson MJ (1992) Growth of the seagrass Heterozostera tasmanica limited by nitrogen in Port Phillip Bay, Australia. Mar Ecol Prog Ser 89: 269-275

Chisholm JRM, Dauga C, Ageron E, Grimont PAD, Jaubert JM (1996) 'Roots' in mixotrophic algae. Nature 381:382

Cowie GL, Hedges JI (1992). Sources and reactivities of amino acid in a coastal marine environment. Limnol Oceanogr 37:703-724

Evrard V, Kiswara W, Bouma TJ, Middelburg JJ (2005) Nutrient dynamics of seagrass ecosystems: ${ }^{15} \mathrm{~N}$ evidence for the importance of particulate organic matter and root systems. Mar Ecol Prog Ser 295:49-55

Fry B (2006) Stable isotope ecology. Springer, New York, NY > Goecke F, Labes A, Wiese J, Imhoff JF (2010) Chemical interaction between marine macroalgae and bacteria. Mar Ecol Prog Ser 409:267-300

Hansen HP, Koroleff F (1999) Determination of nutrients. In: Grasshoff K, Kremling K, Ehrhardt M (eds) Methods of seawater analysis, 3rd edn. Wiley-VCH, Weinheim, p 159-229

Hansen JW, Udy JW, Perry CJ, Dennison WC, Lomstein BA (2000) Effect of the seagrass Zostera Capricorni on sediment microbial processes. Mar Ecol Prog Ser 199:83-96

> Harrison KA, Bol R, Bardgett RD (2007) Preferences for different nitrogen forms by coexisting plant species and soil microbes. Ecology 88:989-999

Jensen SI, Kühl M, Priemé A (2007) Different bacterial communities associated with the roots and bulk sediment of the seagrass Zostera marina. FEMS Microbiol Ecol 62:108-117

> Kirchman D, K'Nees E, Hodson R (1985) Leucine incorporation and its potential as a measure of protein-synthesis by bacteria in natural aquatic systems. Appl Environ Microbiol 49:599-607

Linares F, Sundbäck K (2006) Uptake of dissolved free amino acids (DFAA) by microphytobenthic communities. Aquat Microb Ecol 42:175-186

> McCallister SL, Bauer JE, Canuel EA (2006) Bioreactivity of estuarine dissolved organic matter: a combined geochemical and microbiological approach. Limnol Oceanogr 51: 94-100

McCarthy MD, Hedges JI, Benner R (1998) Major bacterial 
contribution to marine dissolved organic nitrogen. Science 281:231-234

McCarthy MD, Benner R, Lee C, Hedges JI, Fogel ML (2004) Amino acid carbon isotopic fractionation patterns in oceanic dissolved organic matter: an unaltered photoautotrophic source for dissolved organic nitrogen in the ocean? Mar Chem 92:123-134

Mozdzer TJ, Zieman JC, McGlathery KJ (2010) Nitrogen uptake by native and invasive temperate coastal macrophytes: importance of dissolved organic nitrogen. Estuaries Coasts 33:784-797

Mulholland MR, Gobler CJ, Lee C (2002) Peptide hydrolysis, amino acid oxidation, and nitrogen uptake in communities seasonally dominated by Aureococcus anophagefferens. Limnol Oceanogr 47:1094-1108

Mulholland MR, Boneillo G, Minor EC (2004) A comparison of $\mathrm{N}$ and $\mathrm{C}$ uptake during brown tide (Aureococcus anophagefferens) blooms from two coastal bays on the east coast of the USA. Harmful Algae 3:361-376

Nilsson C, Sundbäck K (1996) Amino acid uptake in natural microphytobenthic assemblages studied by microautoradiography. Hydrobiologia 332:119-129

Palenik B, Morel FMM (1991) Amino oxidases of marine phytoplankton. Appl Environ Microbiol 57:2440-2443

Paul VJ, Fenical W (1987) Natural products chemistry and chemical defence in tropical marine algae of the phylum Chlorophyta. In: Scheuer PJ (ed) Bioorganic marine chemistry, Vol. 1. Springer, Berlin, p 1-29

Pete R, Davidson K, Hart MC, Gutierrez T, Miller AEJ (2010) Diatom derived dissolved organic matter as driver of bacterial productivity: the role of nutrient limitation. J Exp Mar Biol Ecol 391:20-26

Romero J, Lee KS, Pérez M, Mateo MA, Alcoverro T (2006) Nutrient dynamics in seagrass ecosystems. In: Larkum AWD, Orth RJ, Duarte CM (eds) Seagrasses: biology, ecology and conservation. Springer, Dordrecht, p 227-254

Seitzinger SP, Sanders RW, Styles R (2002) Bioavailability of don from natural and anthropogenic sources to estuarine plankton. Limnol Oceanogr 47:353-366

Solomon CM, Glibert PM (2008) Urease activity in five phytoplankton species. Aquat Microb Ecol 52:149-157

Stapel J, Aarts TL, van Duynhoven BHM, de Groot JD, van den Hoogen PHW, Hemminga MA (1996) Nutrient uptake by leaves and roots of the seagrass Thalassia hemprichii in the Spermonde archipelago, Indonesia. Mar Ecol Prog Ser 134:195-206

Editorial responsibility: Hans Heinrich Janssen, Oldendorf/Luhe, Germany
Stapel J, Hemminga MA, Bogert CG, Maas YEM (2001) Nitrogen $\left({ }^{15} \mathrm{~N}\right)$ retention in small Thalassia hemprichii seagrass plots in an offshore meadow in south Sulawesi, Indonesia. Limnol Oceanogr 46:24-37

- Stepanauskas R, Edling H, Tranvik LJ (1999) Differential dissolved organic nitrogen availability and bacterial aminopeptidase activity in limnic and marine waters. Microb Ecol 38:264-272

Stepanauskas R, Laudon H, Jørgensen NOG (2000) High DON bioavailability in boreal streams during a spring flood. Limnol Oceanogr 45:1298-1307

Stoecker DK, Gustafson DE (2003) Cell-surface proteolytic activity of photosynthetic dinoflagellates. Aquat Microb Ecol 30:175-183

> Tarutani K, Niimura Y, Uchida T (2004) Short-term uptake of dissolved organic nitrogen by an axenic strain of Ulva pertusa (Chlorophyceae) using ${ }^{15} \mathrm{~N}$ isotope measurements. Bot Mar 47:248-250

Thursby GB, Harlin MM (1984) Interaction of leaves and roots of Ruppia maritima in the uptake of phosphate, ammonia and nitrate. Mar Biol 83:61-67

> Tyler AC, McGlathery KJ, Anderson IC (2003) Benthic algae control sediment-water column fluxes of organic and inorganic nitrogen compounds in a temperate lagoon. Limnol Oceanogr 48:2125-2137

Tyler AC, McGlathery KJ, Macko SA (2005) Uptake of urea and amino acids by the macroalgae Ulva lactuca (Chlorophyta) and Gracilaria vermiculophylla (Rhodophyta). Mar Ecol Prog Ser 294:161-172

> Van Engeland T, Soetaert K, Knuijt A, Middelburg JJ (2010) Dissolved organic nitrogen dynamics in the North Sea: a time series analysis (1995-2005). Estuar Coast Shelf Sci 89:31-42

von Felten S, Buchmann N, Scherer-Lorenzen M (2008) Preferences for different nitrogen forms by coexisting plant species and soil microbes: comment. Ecology 89: 878-879

> Vonk JA, Middelburg JJ, Stapel J, Bouma TJ (2008) Dissolved organic nitrogen uptake by seagrasses. Limnol Oceanogr 53:542-548

Zehr JP, Ward BB (2002) Nitrogen cycling in the ocean: new perspectives on processes and paradigms. Appl Environ Microbiol 68:1015-1024

Ziegler S, Benner R (1999) Nutrient cycling in the water column of a subtropical seagrass meadow. Mar Ecol Prog Ser 188:51-62

Submitted: May 7, 2010; Accepted: January 24, 2011

Proofs received from author(s): March 28, 2011 